\title{
Development of a Trailer-type Series Hybrid System to Extend Driving Range of EV.
}

\author{
Takashi Ashida*
}

\begin{abstract}
Poor or absent infrastructure for supplying energy for electric vehicles (EVs) and a short driving range prevent the widespread use of EVs in Japan. In this study, an inexpensive series hybrid system, consisting of an EV and a trailer-type engine generator (TEG), was developed to extend the driving range. A trailer and a gasoline operating engine generator, which can be supplied at common gas stations, were designed and manufactured. Several driving experiments to evaluate the performance of this new system were carried out. Considering the total weight of 1,900 $\mathrm{kg}$ and the small engine, the average fuel economy over $11 \mathrm{~km} /$ liter obtained in the experiment was notable. This series hybrid system achieved a better performance than the plug-in hybrid system which has been developed recently. The Japanese government agreed to register this TEG as a special-purpose vehicle for emergency power supply in July 2007.
\end{abstract}

Keywords: Battery Electric Vehicles, Hybrid Electric Vehicles, Series HEVs, Plug-in Hybrid, Driving Range.

\section{INTRODUCTION}

Since its invention at the end of the nineteenth century, the automobile has provided useful transportation. However, vast consumption of fossil fuel through the wide use of internal combustion engine vehicles (ICEVs) has brought about serious problems, such as depleting the world supply of fossil fuel, air pollution and global warming. Electric vehicles (EVs) have gained attention as an effective solution to some of these problems, but some difficulties need to be overcome before they are widely used [1].

One reason for limited use of EVs is that they are not as convenient as ICEVs. Because of a fully developed infrastructure, such as easy access to gas stations for ICEVs, their driving range in developed countries is practically infinite. In contrast, AC energy supply stations for EVs are scarce and this presents a major obstacle to be overcome. Another challenge for EVs is long re-charging time [1]. Because of this, mobility of EVs with a short driving range is currently restricted. Several solutions have been explored. Some have developed gasoline-reforming fuel cells which enable EVs by utilizing existing gas stations to re-charge; but they are not yet practical enough yet. In spite of various efforts such as improving capacities of batteries by

* TGMY Co., Ltd. / Osaka City University,

3-3-11, Kire, Hirano-ku, Osaka, 547-0027, Japan.

Phone: +81-6-4302-3367, Fax: +81-6-4302-3368.

E-mail: ashida@TGMY.jp using Li-ion batteries and improving speed for re-charging, they are still in an experimental stage. Especially when the needs for better infrastructures for EVs are considered, these efforts do not yet bring us the light at the end of the tunnel. This author considers an inexpensive trailer-type series hybrid system to extend the driving range of EVs as a solution and has developed a special generator for this purpose.

In order to make a trailer-type series hybrid system practical, I raised three goals:

(1) The costs of a generator for the trailer-type series hybrid system should be less than $20 \%$ of the costs for the Li-ion batteries of the same weight;

(2) The total weight of the trailer-type series hybrid system including the trailer should be less than that of a general-purpose generator of the same output power;

(3) The costs of the trailer-type series hybrid system including the trailer should be less than those of a general-purpose generator of the same output power.

This paper presents first, the development process of the trailer-type series hybrid system which includes the special generator and, second, its performance and practicality which are examined through several driving experiments. 


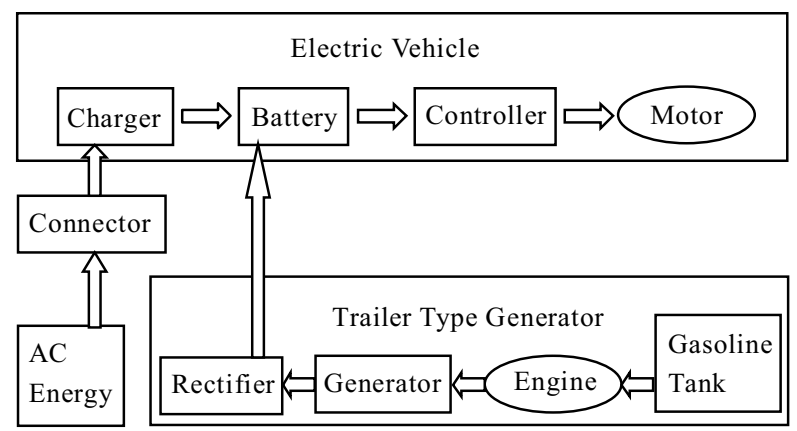

Fig. 1 Block Diagram of the EV System.

\section{TRAILER-TYPE ENGINE GENERATOR (TEG)}

As an intermediate solution until the abovementioned challenges are met, development of a trailer-type series hybrid system is considered in Japan. A special engine generator which meets Japanese regulations and which can be pulled by EVs was developed for this new system [2] and it is called a trailer-type engine generator (TEG). The use of TEGs is not limited to EVs but can be used in many other cases such as emergency situations due to disasters.

The block diagram of the system, the outline of the TEG and a photograph of this system are shown in Fig. 1, Fig. 2 and Fig. 3 respectively. The specifications of the system are shown in the Appendix.

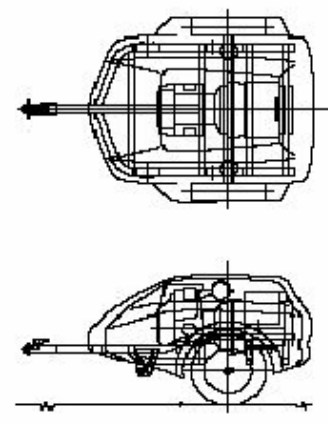

Fig. 2 Outline of the Trailer-type Generator.

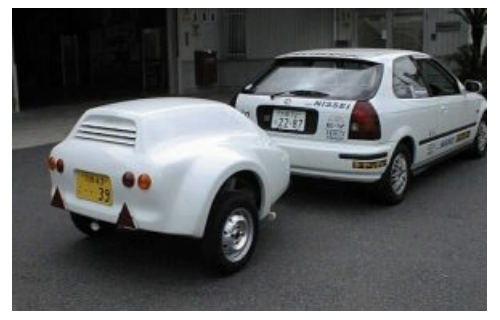

Fig. 3 (Left) Trailer-type generator. (Right) Electric vehicle.

\section{DEVELOPING AN ENGINE GENERATOR}

The engine generator (EG) used in the system should be small and light-weigh because it is installed on a trailer to be pulled by an EV. All the commercially available EGs in Japan which generates over $10 \mathrm{~kW}$ output are designed for emergency or temporary use; they are too large and too heavy to use on a small trailer (Fig. 4 and Fig. 5). Since a small-sized, high-power EG could not be found, a small and lightweight EG specially designed for this series-hybrid system had to be developed. In order to do so, the author selected the most suitable generator and engine.

\subsection{Selecting a Generator}

Comparison of generators produced by domestic and international manufacturers revealed that generators for small boats are relatively compact and light. After comparing generators for small boats, a generator manufactured by NEW AGE INTERNATIONAL (Fig. 6) was chosen because it was relatively inexpensive among the generators whose size and weight met the requirements for this system.

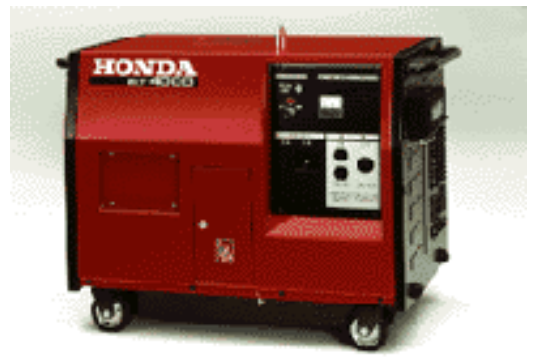

Fig. $43 \mathrm{Ph}, 200 \mathrm{~V}, 5$ kVA generator (HONDA). Dimension: 965x590x730 mm. Weight: $175 \mathrm{~kg}$. Price: US\$ 6,000.

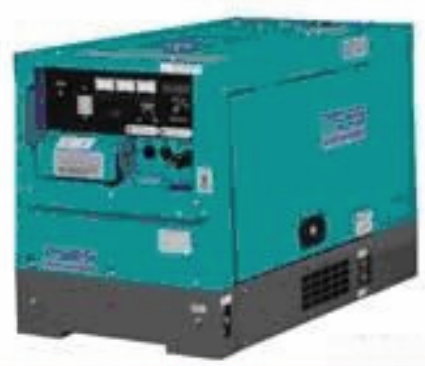

Fig. $53 \mathrm{Ph}, 200 \mathrm{~V}, 13 \mathrm{kVA}$ generator (HOKUETSU). Dimension: 1480x650x950 mm. Weight: $520 \mathrm{~kg}$. Price: US\$12,000. 


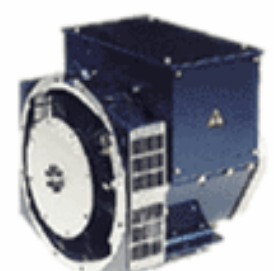

Fig. 6 BCI-162E generator manufactured by NEW AGE INTERNATIONAL (England). Rating: $3 \mathrm{Ph}, 60$ Hz, 220 V, 18.8 kVA, 15 kW. Dimension: 360x410x455 $\mathrm{mm}$. Weight: $110 \mathrm{~kg}$. Price: US\$ 1,000.

\subsection{Selecting an Engine}

Because of its small size, light weight, simple structure, and small emission of carbon dioxide, a multipurpose air-cooled four-stroke cycle engine was selected for the system. An engine manufactured by HONDA (Fig. 7) was chosen mainly because its maximum output of 20 PS is attained at the output rotation speeds of $3600 \mathrm{rpm}$ which matches the rotation number of the generator at $60 \mathrm{~Hz}$ operation.
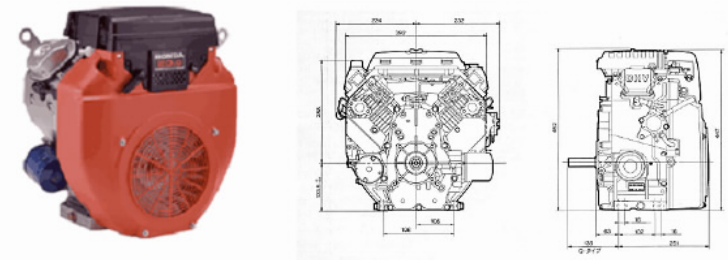

Fig. 7 GX620 multipurpose engine manufactured by HONDA (Japan). Dimension: 386x456x452 mm. Weight: $42.5 \mathrm{~kg}$. Price: US\$ 1,170 .

\subsection{Combining the Generator and the Engine}

By designing a mount and a flange and combining the selected generator and engine, the integrated EG was manufactured (Fig. 8). Its size and weight are small enough for installing on the trailer (see next section for details of the trailer).
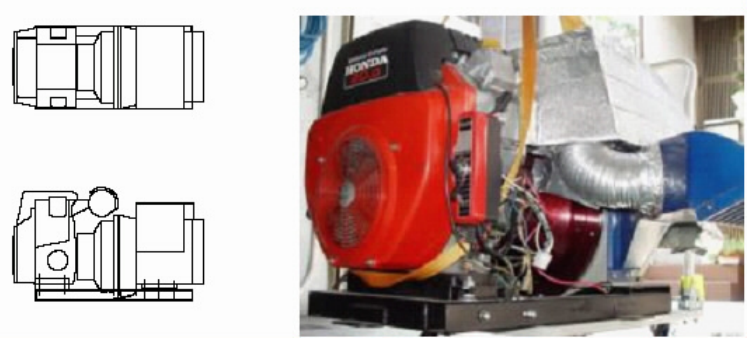

Fig. 8 Connection of the generator and the engine. Rating: $3 \mathrm{Ph}, 60 \mathrm{~Hz}, 220 \mathrm{~V}, 18.8 \mathrm{kVA}, 15 \mathrm{~kW}$. Dimension: 980x460x490 mm. Weight: $170 \mathrm{~kg}$. Red flange is shown in the center of the photo. The generator is covered with a heat shield.

\section{DEVELOPING A TRAILER}

A trailer having sufficient strength and performance required by Japanese Road Trucking Vehicle Law and the safety standards set by Japanese regulations was developed. By its size and weight, the trailer is classified as a light-vehicle according to the Japanese regulations. Since there was no legal category of trailer-type light-vehicle engine generator in Japan, the trailer was at first registered as a full-trailer for carrying cargo [3][4]. At the end of 2006, seven years after this hybrid system was developed, the Ministry of Land, Infrastructure and Transport of Japan agreed to change the registration of the trailer-type engine generator, in the next vehicle inspection in July, 2007, to a special-purpose vehicle for emergency power supply.

\subsection{Developing a Frame}

With the technical assistance of engineers from the Light Motor Vehicle Inspection Organization, a frame specially designed for this system was developed (Fig. 9) [3][4] and structural analyses (such as analyses of load distribution, braking capacity, stability, minimum rotation radius, strength of frame, etc.) were conducted in order to ensure its strengths, practicality and compliance with safety standards for a ground transportation vehicle. The completed document qualifying the frame for the safety standards was 22 pages long. Instead of giving all the data here, the result of structural analysis by CAD is shown as an example (see Fig. 10). The analysis confirmed that the strength of the frame was sufficient for the legal regulations.

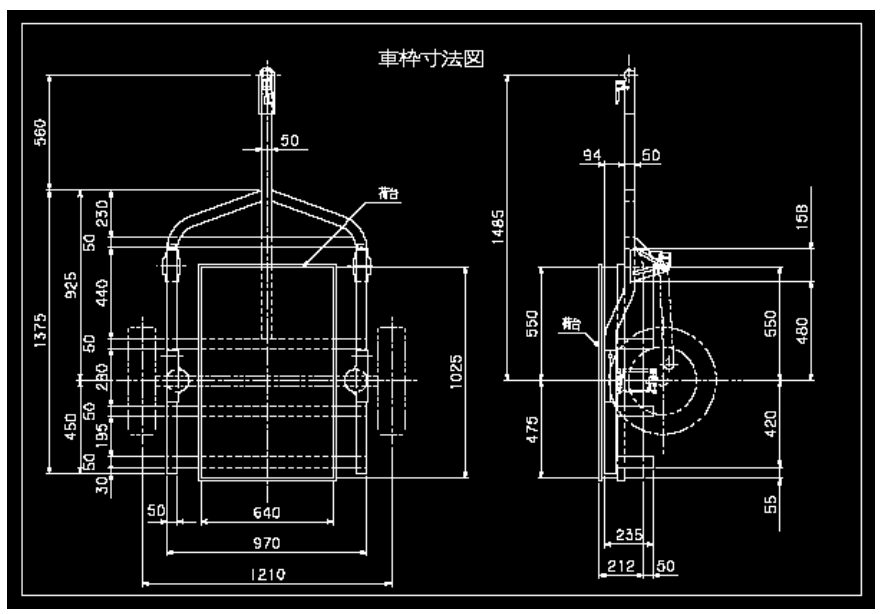

Fig. 9 Dimensions of the frame in $\mathrm{mm}$. 


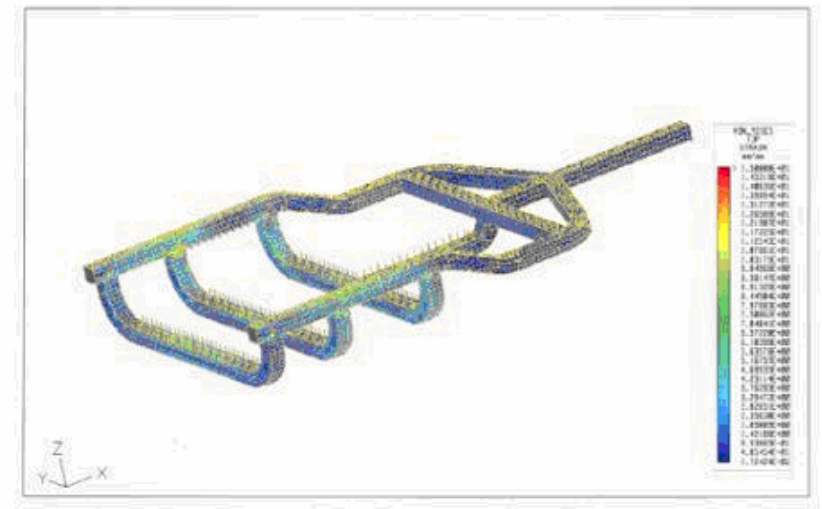

Fig. 10 Structural analysis by CAD. Red indicates that load is concentrated and blue indicates dispersed.

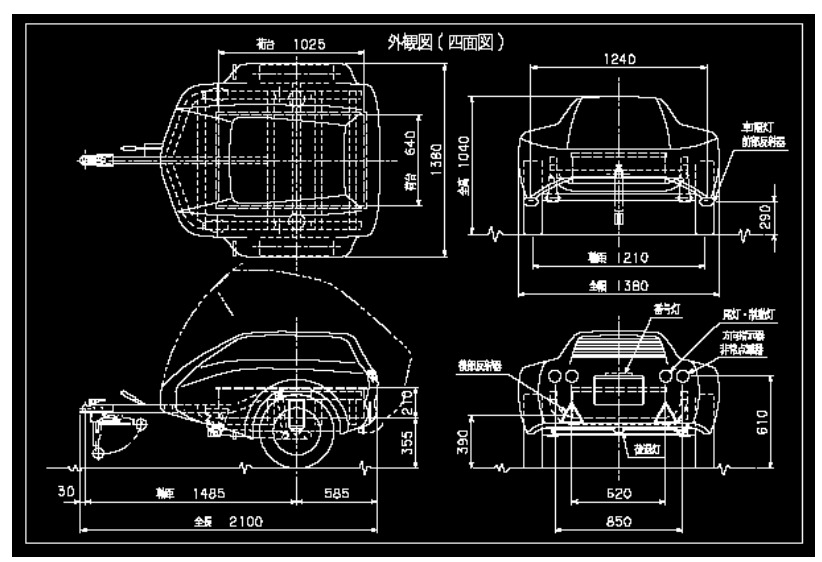

Fig. 11 Dimensions of the body of the trailer in $\mathrm{mm}$.

\subsection{Developing a Car Body}

Since the trailer-type engine generator is used with an EV, its appearance should be united with the EV. A body for the frame with FRP focusing on function and design was manufactured (Figs. 11-13)
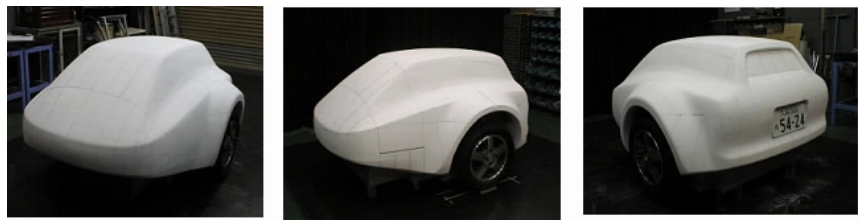

Fig. 12 Mock-up of the body of the trailer.

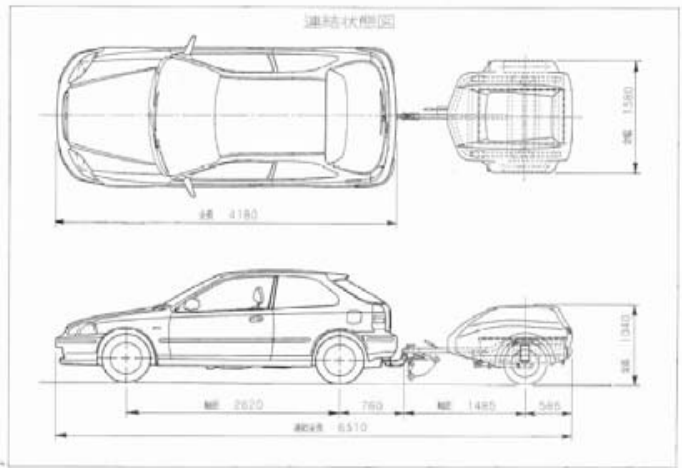

Fig. 13 Connection of the EV and the trailer-type engine generator.

\section{DRIVING EXPERIMENTS}

In order to evaluate the performance of the trailer-type series hybrid system, an EV with this system entered 5 rallies in Japan (Fig. 14 and Fig. 15). The results are shown in Table 1 and in Fig. 16. More than $90 \%$ of Rallies 1 to 4 and about $40 \%$ of Rally 5 involve highway driving.
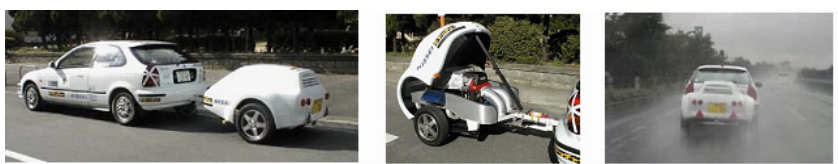

Fig. $14 \mathrm{EV}$ with the trailer-type engine generator (TEG). (Left) EV and TEG connected. (Center) Engine generator on the trailer. (Right) Photograph of the series hybrid in rainy Tomei-highway.

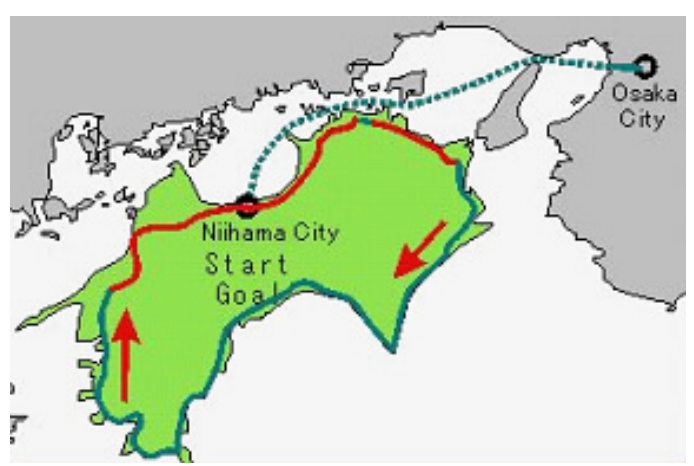

Fig. 15 Route map of the Shikoku EV Ekiden (Exp. 5). (Red) Highways. (Green) Local roads. (Dotted) Ferry. [5] 


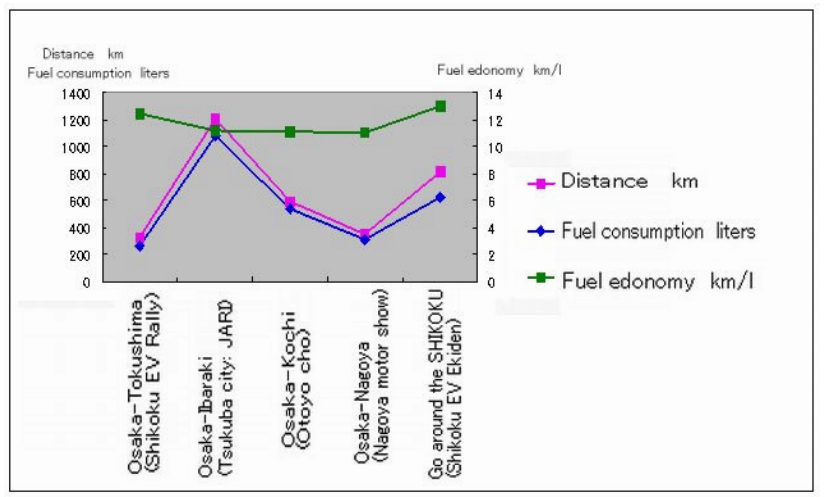

Fig. 16 Summary of driving experiments.

\section{EVALUATION OF THE SYSTEM}

In this section, the achievement of the goal described in the introduction is assessed.

\subsection{Costs and Weight of the Trailer-type Engine Generator (TEG)}

The cost for manufacturing the TEG was $¥ 750,000$ (US\$6,250), its dry weight is $297.5 \mathrm{~kg}$, and the total weight is $325 \mathrm{~kg}$. Details of costs and weight are shown in Table 2.

Table 1 Results of driving experiments.

\begin{tabular}{|c|c|l|c|c|c|c|}
\hline & Date & \multicolumn{1}{|c|}{ Destination (Round Trip) } & Distance & Fuel consumption & Fuel economy & Time \\
\hline 1 & 99.08 & Osaka-Tokushima(Shikoku EV Rally) & $330 \mathrm{~km}$ & 26.7 liters & $12.4 \mathrm{~km} / 1$ & $4 \mathrm{~h} 15 \mathrm{~m}$ \\
\hline 2 & 99.09 & Osaka-Ibaraki (Tsukuba city: JARI) & $1204 \mathrm{~km}$ & 107.9 liters & $11.16 \mathrm{~km} / 1$ & $20 \mathrm{~h} 57 \mathrm{~m}$ \\
\hline 3 & 99.10 & Osaka-Kochi (Otoyo-cho) & $597 \mathrm{~km}$ & 53.9 liters & $11.08 \mathrm{~km} / 1$ & $10 \mathrm{~h} 45 \mathrm{~m}$ \\
\hline 4 & 99.11 & Osaka-Nagoya (Nagoya motor show) & $350 \mathrm{~km}$ & 31.6 liters & $11.06 \mathrm{~km} / 1$ & $5 \mathrm{~h} 45 \mathrm{~m}$ \\
\hline 5 & 02.08 & Round Shikoku Island (Shikoku EV Rally) & $810 \mathrm{~km}$ & 62.3 liters & $13.00 \mathrm{~km} / 1$ & $17 \mathrm{~h} 05 \mathrm{~m}$ \\
\hline \multicolumn{2}{|c|}{ Total } & $3291 \mathrm{~km}$ & 282.4 liters & $11.65 \mathrm{~km} / 1$ & $58 \mathrm{~h} 47 \mathrm{~m}$ \\
\hline
\end{tabular}

Table 2 Costs and Weight of the TEG ( $¥ 120=$ US\$ 1 ).

\begin{tabular}{|c|c|c|c|}
\hline Parts & Weight & Price (¥) & Price (US\$) \\
\hline BCI-162E Generator (NEW AGE INTERNATIONAL) & $42.5 \mathrm{~kg}$ & 120,000 & 1,000 \\
\hline GX620 general-purpose engine (HONDA) & $110 \mathrm{~kg}$ & 140,000 & 1,170 \\
\hline Mount base, Coupling, Exhaust air duct & $20 \mathrm{~kg}$ & 50,000 & 420 \\
\hline Gasoline tank (30 liters) & $5(27.5) \mathrm{kg}$ & 30,000 & 250 \\
\hline Subtotal of engine generator & $172.5(200) \mathrm{kg}$ & 340,000 & 2,840 \\
\hline Frame & $30 \mathrm{~kg}$ & 50,000 & 420 \\
\hline Axle, Suspension, Tires & $35 \mathrm{~kg}$ & 60,000 & 500 \\
\hline Controller, Rectifier & $5 \mathrm{~kg}$ & 75,000 & 625 \\
\hline Car body & $20 \mathrm{~kg}$ & 150,000 & 1,250 \\
\hline Electric equipments & $15 \mathrm{~kg}$ & 25,000 & 210 \\
\hline Deck and others & $20 \mathrm{~kg}$ & 50,000 & 420 \\
\hline Subtotal of trailer & $125 \mathrm{~kg}$ & 410,000 & 3,425 \\
\hline Total & $297.5(325) \mathrm{kg}$ & 750,000 & 6,250 \\
\hline
\end{tabular}


Table3 Fuel consumption of our series hybrid system. Theoretical energy of 1 liter gasoline is converted to the low heat value of $8776 \mathrm{Wh}$.

\begin{tabular}{|l|r|r|r|r|}
\hline & \multicolumn{1}{|c|}{ Distance } & $\begin{array}{l}\text { Electrical power } \\
\text { consumption }\end{array}$ & $\begin{array}{l}\text { Conversion to gasoline } \\
\text { consumption }\end{array}$ & \multicolumn{1}{l|}{ Fuel economy } \\
\hline 2nd Shikoku EV rally, 1999 & $283.1 \mathrm{~km}$ & $23.220 \mathrm{kWh}$ & 2.65 liters & $106.8 \mathrm{~km} / 1$ \\
\hline 3rd Shikoku EV rally, 2000 & $364.0 \mathrm{~km}$ & $25.917 \mathrm{kWh}$ & 2.95 liters & $123.4 \mathrm{~km} / 1$ \\
\hline 4th Shikoku EV rally, 2001 & $344.0 \mathrm{~km}$ & $27.847 \mathrm{kWh}$ & 3.17 liters & $108.5 \mathrm{~km} / 1$ \\
\hline 5th Shikoku EV rally, 2002 & $294.4 \mathrm{~km}$ & $23.294 \mathrm{kWh}$ & 2.65 liters & $111.1 \mathrm{~km} / 1$ \\
\hline Total & $1285.5 \mathrm{~km}$ & $100.278 \mathrm{kWh}$ & 11.43 liters & $112.5 \mathrm{~km} / 1$ \\
\hline
\end{tabular}

Table 4 Comparison of fuel economy between a plug-in hybrid system and this series hybrid system. PHEV32 and PHEV96 are plug-in hybrid EVs which can drive 32 and $96 \mathrm{~km}$, respectively [7].

\begin{tabular}{|l|l|c|}
\hline Type & & $\begin{array}{l}\text { Conversion to fuel } \\
\text { economy }\end{array}$ \\
\hline Plug-in HEV & PHEV32, Central Research Institute of Electric Power Industry & $49.8 \mathrm{~km} / 1$ \\
\hline Plug-in HEV & PHEV96, Central Research Institute of Electric Power Industry & $48.4 \mathrm{~km} / 1$ \\
\hline Series HEV & EV CIVIC, this study (lead acid batteries) & $112.5 \mathrm{~km} / 1$ \\
\hline
\end{tabular}

\subsection{Assessment of the Goal Attainment}

Inexpensive Li-ion batteries made in Korea manufactured by Micro Vehicle Lab (24 V, $15 \mathrm{Ah}$, dimension: $72 \times 155 \times 270 \mathrm{~mm}$, weight: $4.2 \mathrm{~kg}$, price: $¥ 134,000=$ US\$ 1,116 per battery) are compared with the engine generator for the trailer-type series hybrid system. When the batteries are connected in 12-series 4 -parallel, the output will be $288 \mathrm{~V}, 60 \mathrm{Ah}$, almost equal to the capacity of the lead-acid battery loaded on the EV.

Goal 1: The costs of a generator for the trailer-type series hybrid system should be less than $20 \%$ of the costs for the Li-ion batteries of the same weight. The cost for these Li-ion batteries is $¥ 6,432,000$ (US\$53,600). The cost of the engine generator for this system $(¥ 7,500)$ is $11.6 \%$ of that of Li-ion battery.

Goal 2: The total weight of the trailer-type series hybrid system including the trailer should be less than that of a general-purpose generator of the same output power. A mobile engine generator TLG-L3ESY by DENYO which has similar power output was used for the comparison. The dry weight of the TEG $(325 \mathrm{~kg})$ is $79.5 \%$ of that of TLG-L3ESY by DENYO $(406 \mathrm{~kg})$.

Goal 3: The costs of the trailer-type series hybrid system including the trailer should be less than those of a general-purpose generator of the same output power.

The cost of the TEG $(¥ 750,000)$ is $52 \%$ of that of a mobile engine generator TLG-L3ESY (DENYO) costing $¥ 1,440,000$ (US\$ 12,000).

Thus the three goals were successfully achieved. The advantage of using a general-purpose engine and a generator for small fishing boats is not limited to the cost. It also allows us to avoid the complexity in structure which derives from using motorcycle engines [6]. The fact that the TEG can be used without problems even seven years after development indicates the durability of the system consisting of a simple general-purpose engine and a generator for small fishing boats

\section{COMPARISON TO THE PLUG-IN HYBRID SYSTEM}

The plug-in hybrid electric vehicles are getting increasing attention. In the plug-in hybrid system, more batteries than a conventional hybrid vehicle are loaded to extend the performance. However, its cost and efficiency cannot be optimal because the system always carries batteries and generators. In this range-extending series hybrid system, the TEG can be uncoupled when it is not needed (such as in a case of short-distance driving). Therefore, the series hybrid system may well achieve a better performance. Table 3 shows the fuel consumption recorded in Shikoku EV rallies. Table 4 compares the fuel consumption between a plug-in hybrid system [7] and the series hybrid system. The current trailer-type series hybrid system achieved twice as much improved fuel economy than the plug-in hybrid system. 


\section{CONCLUSION AND DISCUSSION}

The TEG was developed to meet the current challenges for EVs discussed in the introduction. Considering the total weight of $1900 \mathrm{~kg}$ (EV $1414 \mathrm{~kg}+$ TEG $375 \mathrm{~kg}+$ people $2 \times 55 \mathrm{~kg}$ ) and the small displacement of the engine $(614 \mathrm{cc})$, the average fuel economy of over $11 \mathrm{~km} /$ liter is notable. This high performance is enabled by a constant running of the engine generator without depending on the vehicle velocity. Advantages of the series hybrid system in cost and weight were demonstrated. Unlike the plug-in hybrid system, the TEG in this series hybrid system can be uncoupled from the EV. Therefore the EV can run using only built-in batteries for short driving distances and with the TEG for long driving distances to achieve better fuel economy performance than the plug-in hybrid system. In case of a disaster, the TEG can quickly be trailed by an EV to stricken areas to be used as a power source. This is an additional value of the TEG developed in this study.

\section{APPENDIX}

Specifications of the series hybrid system.

Table 5 Specifications of the EV.

\begin{tabular}{|c|c|}
\hline Model & HONDA CIVIC (Sedan) \\
\hline Motor Type & AC 3 Ph Induction Motor \\
\hline Motor Power & $\begin{array}{c}\text { Nominal Power : } 18 \mathrm{~kW} \\
\text { Maximum Power : 67 kW }\end{array}$ \\
\hline Max. Torque & $140 \mathrm{Nm}$ \\
\hline Revolving Speed & $0-12000 \mathrm{rpm}$ \\
\hline Curb Weight & $1318 \mathrm{~kg}(\mathrm{Exp}: 1414 \mathrm{~kg})$ \\
\hline Max. Weight & $1538 \mathrm{~kg}(4 \mathrm{seats})$ \\
\hline Max. Speed & Over $130 \mathrm{~km} / \mathrm{hr}$ \\
\hline Length & $4180 \mathrm{~mm}$ \\
\hline Width & $1695 \mathrm{~mm}$ \\
\hline Height & $1375 \mathrm{~mm}$ \\
\hline
\end{tabular}

Table 6 Specifications of the trailer.

\begin{tabular}{|c|l|}
\hline Model Type & Prototype \\
\hline Model Name & HB-EG15 \\
\hline Car Type & Full trailer (truck) \\
\hline Curb Weight & $125 \mathrm{~kg}$ \\
\hline Max. Load & $250 \mathrm{~kg}$ \\
\hline Total Weight & $375 \mathrm{~kg}$ \\
\hline Length & $2130 \mathrm{~mm}$ \\
\hline Width & $1380 \mathrm{~mm}$ \\
\hline Height & $1040 \mathrm{~mm}$ \\
\hline
\end{tabular}

Table 7 Specifications of the engine generator.

\begin{tabular}{|c|c|c|}
\hline \multirow{3}{*}{ 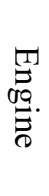 } & Type & $\begin{array}{l}\text { Four stroke overhead valve } \\
90 \mathrm{deg} \text { V-Twin } 614 \mathrm{cc} \\
\end{array}$ \\
\hline & Max. Output & $20 \mathrm{hp}$ \\
\hline & Cooling system & Forced air \\
\hline \multirow{6}{*}{ 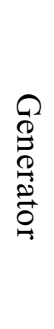 } & Type & Brushless, self excited \\
\hline & Coupling & Flexible coupling \\
\hline & Voltages & AC $3 \mathrm{Ph} \quad 220-250 \mathrm{~V}$ \\
\hline & Output & $15 \mathrm{~kW}$ \\
\hline & Control & AVR Type \\
\hline & Cooling System & Forced Air \\
\hline \multirow{4}{*}{ 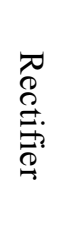 } & Rectifier & 1600 V 3 Ph Diodes Bridge \\
\hline & Current capacity & 5x30 A Max.150 A \\
\hline & Input & AC $3 \mathrm{Ph} \mathrm{220-250} \mathrm{V}$ \\
\hline & Output & DC $308-350 \mathrm{~V}$ \\
\hline \multirow{4}{*}{ 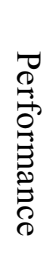 } & Revolving Speed & $3600 \mathrm{rpm}$ \\
\hline & Max Power & DC $350 \mathrm{~V} 15 \mathrm{~kW}$ \\
\hline & Nominal Power & DC $350 \mathrm{~V} 11 \mathrm{~kW}$ \\
\hline & Cruising Speed & $\begin{array}{l}70-75 \mathrm{~km} / \mathrm{hr} \\
\text { without battery discharge }\end{array}$ \\
\hline
\end{tabular}

\section{REFERENCES}

[1] H. Shimizu: "All about Electric Vehicles", Nikkan Kogyo Shimbun, LTD., 1992.

[2] N. Mihori: "AC propulsion Honda in EV World", Nigen-sha, Tokyo, 1995.

[3] Kinki Automobile Service Liaison Association: "Road Trucking Vehicle Law", 1995.

[4] Automobile engineering editing committee, Automobile engineering, Sankai-do, Tokyo, 1988.

[5] K. Miyashita: "Comparative study between Shikoku EV Rally in Japan and Tour de Sol in USA", J. Asian Electric Vehicles, Vol.1, No.1, pp. 367-372, 2003.

[6] T. B. Gage: "Low-emission range extender for electric vehicles", AC Propulsion Inc., 1997.

[7] R. Hiwatari: "Effect of introducing plug-in hybrid vehicles on the electricity demand in Japan", Research Report, L05008, Central Research Institute of Electric Power Industry, 2006.

\section{ACKNOWLEDGEMENT}

The author earnestly thanks Prof. Shigeyuki Minami for his advice in preparing the manuscript and $\mathrm{Mr}$. Juichi Terauchi (Head of Light Motor Vehicle Inspection Organization, Osaka office) for his kind instructions in registering the trailer, Dr. Go Ashida and Ms. Yukiyo Nakayama-Ashida for their indispensable help in preparing the manuscript, Ms. Yasuko Ashida and Mr. Masato Ashida for their support for the project, Dr. Atsuko Matsuoka and Dr. John Sorenson for proofreading the manuscript. 


\section{BIOGRAPHIES}

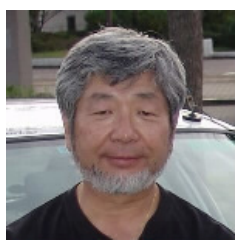

Takashi Ashida is a doctoral course student, Graduate school of engineering, Osaka City University. President of TGMY Co. Ltd.

Born in 1947. Employed by a manufacturer of peripheral equipments of room air conditioners and satellite dishes until March 2005. Self-employed after March 2005. Entered the graduate school as an adult student in April 2006. 